\title{
Stanisław Keturakis - Litwin w służbie rosyjskiej oświaty na terenie guberni piotrkowskiej w latach 1895-1914
}

\begin{abstract}
Stanislaw Keturakis - a Lithuanian in the service of Russian education in the area of Piotrków province in the years 1895-1914

At the end of the 19th century, the teaching profession was the aspiration of many peasant sons. The position of a teacher ensured a modest but quite stable income. A Lithuanian, born in 1989, Stanislaw Keturakis, was one of graduates of the Teachers' College in Wejwery near Kaunas. This institution offered a state scholarship. In return for this financial help, its graduates had to accept posts in primary schools determined by educational authorities.

A few graduates of this school, mostly Lithuanians, were sent to work in village schools of Piotrków province. One of them, Stanislaw Keturakis, began his first teaching job in a school in Jedlno. He was confronted with difficult living conditions, the school was only planned to be built. At this time, he married Józefa Birsztejn and they had two sons: Eugeniusz Józef (1901) and Zdzisław Aleksander (1904).

Peasants perceived teachers as tsarist officials. In 1901, S. Keturakis was transferred to Mstów, to work as a teacher, then to Wancerzów, and again back to Jedlno. Taking over a position of a teacher in Zagórze (1907) was clearly a promotion. The school belonged to the private property of Grand Duke Michael Alexandrovich of Russia, a brother of Emperor Nicholas II. The last stage of S. Keturakis's teaching career was his work in a school in Zagórze. Working there in the years 1907-1914, he taught Russian, Polish, Arithmetic, History and Geography. At the end of the summer 1914, he got an opportunity to take over the post of the forester's assistant in Orłow province, but the outbreak of the war made it impossible. Lack of any sources does not allow us to determine what the further life of Stanislaw Keturakis was like.
\end{abstract}

Keywords: teacher, school, countryside, peasants, the First World War 


\section{Wejwery - na drodze do nauczycielskiego patentu}

U schyłku XIX stulecia zawód nauczycielski podobnie jak godność duchownego wydawały się celem aspiracji wielu synów chłopskich, niezamożnych mieszczan czy przedstawicieli zdeklasowanej szlachty. Posada nauczyciela zapewniała skromne, ale w miarę stabilne środki utrzymania, mieszkanie i niewielką działkę pod uprawy rolne. Nie bez znaczenia był okres wakacji czy przerw świątecznych. $Z$ powodu prac polowych od wiosny do jesieni, a zimą ze względu na brak obuwia, okres absencji dzieci w szkołach wiejskich chłopskich wydłużał się znacznie. Na terenie Kongresówki do zawodu nauczycielskiego przygotowywały seminaria nauczycielskie. W latach 18661914 funkcjonowały one w: 1) Białej Podlaskiej, 2) Chełmie Lubelskim, 3) Warszawie, 4) Solcu, 5) Siennicy, 6) Wejwerach 1 , 7) Wymyślinie, a także od 1871 w 8) Łęczycy i 9) Jędrzejowie ${ }^{2}$. W 1910 r. uruchomiono także seminarium w Lodzi.

Funkcjonowanie oświaty ludowej w odniesieniu do ziem Królestwa Polskiego w XIX i na początku XX stulecia od dawna jest już przedmiotem badań3. Zagadnieniom oświaty ludowej dla ziemi częstochowskiej, jednak dotyczącego wcześniejszego okresu, tj. lat 1815-1863, swe opracowanie poświęcił Janusz Lipiec ${ }^{4}$. Natomiast oświaty ludowej Lubelszczyzny dotyczy opracowanie pod redakcją Ryszarda Kuchy ${ }^{5}$. Ważnymi opracowaniami analitycznym są prace Eugenii Podgórskiej ${ }^{6}$ czy Barbary Szabat ${ }^{7}$.

Seminarium Nauczycielskie w Wejwerach, będące w centrum zainteresowania piszącego te słowa, było jedną z placówek przygotowujących przyszłych adeptów

${ }^{1}$ D. Złotkowski, Polacy i Litwini - absolwenci z 1898 roku Seminarium Nauczycielskiego w Wejwerach koto Kowna, w: Wilno i Kresy pótnocno-wschodnie: materialy II Międzynarodowej Konferencji w Biatymstoku 14-17 IX 1994 r. w czterech tomach, 1: Historia i ludzkie losy, red. E. Feliksiak, A. Mironowicz, Białystok 1996. s. 289-313. Zob. także: S. Araszkiewicz, Sytuacja szkolnictwa i oświaty w zaborze rosyjskim w latach 1831-1918. Szkolnictwo elementarne. Okres między powstaniem styczniowym a I wojna światowa, w: Dzieje szkolnictwa i oświaty na wsi polskiej do 1918, t. 1, red. S. Michalski, Ludowa Spółdzielnia Wydawnicza, Warszawa 1982. s. 175. Zob. także informacje o personelu seminariów: R. Kucha, Oświata elementarna w Królestwie Polskim w latach 1864-1914, Krajowa Agencja Wydawnicza, Lublin 1982. s. 81-86.

${ }^{2}$ O wydarzeniach z lat 1905-1907 w Seminarium Nauczycielskim w Jędrzejowie pisała B. Szabat, Walka o szkote polska w okresie rewolucji 1905-1907 r. w guberni kieleckiej, Kieleckie Towarzystwo Naukowe, Kielce 1991, s. 57-66.

${ }^{3}$ K. Poznański, Oświata elementarna w Królestwie Polskim jako przedmiot badań historyczno-pedagogicznych, w: Stan i potrzeby badań nad oświata $i$ wychowaniem w Królestwie Polskim w latach 1815-1915, red. R. Kucha i K. Poznański, Wydawnictwo UMCS, Lublin 1989, s. 51-62.

${ }^{4}$ J. Lipiec, Warunki gospodarcze szkót elementarnych Królestwa Polskiego. Studia nad okręgiem częstochowskim lata 1815-1863, Częstochowa 1989.

${ }^{5}$ R. Kucha, Z problematyki rozbudowy szkolnictwa elementarnego na Lubelszczyźnie w latach 1864-1905, w: Szkolnictwo Lubelszczyzny w XVIII-XX wieku. Studia i rozprawy, red. R. Kucha, Wydawnictwo UMCS, Lublin 1993. s. 83-100.

${ }^{6}$ E. Podgórska, Szkolnictwo elementarne w Lodzi w latach 1808-1914, Państwowe Wydawnictwo Naukowe, Łódź 1966.

${ }^{7}$ B. Szabat, Szkolnictwo poczatkowe Kielc i powiatu kieleckiego w latach 1864-1915, Wyższa Szkoła Pedagogiczna im. Jana Kochanowskiego, Kielce 1983. 
nauczycielstwa. Specyfiką szkoły było to, że przyjmowano tam wyłącznie Litwinów. Placówka, dysponując dobrymi warunkami lokalowymi oraz niezłą kadrą nauczającą, oferowała stypendium rządowe. W zamian po ukończeniu nauki absolwentów obowiązywał nakaz podjęcia pracy w wyznaczonych szkołach elementarnych, w miejscu wskazanym przez władze oświatowe. Szkoła dysponowała dużym ogrodem, polami doświadczalnymi, gdzie młodzież zdobywała podstawowe, praktyczne umiejętności rolnicze, by po podjęciu pracy w szkołach wiejskich dzielić się na wsi wiedzą rolniczą ${ }^{8}$.

Seminarium w Wejwerach (rocznik 1898) ukończyli: (nazwiska wg pisowni litewskiej): 1) Arminaitis Viktoras, 2) Bridickas Pranas, 3) Feteranskas Albertas, 4) Jasaitis Juozas, 5) Kelertas Jonas, 6) Kesleris Edmundas, 7) Keturakis Stasys, 8) Lapinskas Edmundas, 9) Poliakovas Stasys, 10) Risovskis Balys, 11) Sakalauskas Zigmas, 12) Statkevičius Juozas, 13) Ulinskas Viktoras, 14) Vasiliauskas Mecys, 15) Veisas Augustas, 16) Żilinskas Antanas9.

Wśród wymienionych młodych ludzi znalazł się Stanisław Keturakis. Najpierw w 1894 r. wójt gminy Freda (pow. mariampolski, gub. suwalska, wieś Godlewo, poczta Wejwery) na prośbę gospodarza wsi Godlewo Matwieja Keturakisa wystawił zaświadczenie, że uczeń V oddziału gminnej szkoły przy Wejwerskim Seminarium Nauczycielskim Stanisław Keturakis ,jest narodowości litewskiej i pochodzenia chłopskiego"10. Natomiast jego ojciec (niepiśmienny) przedstawił zobowiązanie następującej treści, „Ja niżej podpisany mieszkaniec wsi Godlewo, Gminy Freda, powiatu mariampolskiego, guberni suwalskiej Matwiej Keturakis zobowiązuję się, że jeśli mój syn Stanisław Keturakis opuści seminarium na swoje żądanie lub jeśli będzie usunięty przez kierownictwo seminarium nie ukończywszy pełnego kursu, to na skutek otrzymywania stypendium i utrzymania obowiązuję się zwrócić je do kasy"11.

Ci młodzi ludzie, w ogromnej większości Litwini, decyzją władz Warszawskiego Okręgu Szkolnego zostali skierowani do pracy w wiejskich szkołach elementarnych,

\footnotetext{
${ }^{8}$ Wejwery (lit. Veiveriai) - wieś nad rzeką Jesią, pow. mariampolski, gmina i parafia Wejwery. Położona przy szosie Warszawa-Kowno. W opustoszałym, obszernym budynku dawnej poczty znajdowała się siedziba Seminarium Nauczycielskiego; Słownik Geograficzny Królestwa Polskiego (dalej: SGKP), t. 13, Warszawa 1893, s. 196. Zdjęcia przedstawiające wygląd i stan zachowania wspomnianych budynków (lipiec 1993 r.); patrz. D. Złotkowski, Życie zawodowe i rodzinne Stanisława Polakowskiego 1880-1943 nauczyciela szkót wiejskich w świetle jego notatek $i$ korespondencji, Częstochowa 1995, s. 92-93. Najpełniej o Seminarium w Wejwerach napisał J. Kudirka, Veiveriu mokytoju seminarija 1866-1918, Vilnius 1970, s. 68-80. Ważne uzupełnienia podaje także R. Kucha, Stan i potrzeby badań nad oświata i wychowaniem w Królestwie Polskim w latach 1815-1915, red. R. Kucha i K. Poznański, s. 80, 87.

${ }^{9}$ Lista nazwisk absolwentów Seminarium Nauczycielskiego w Wejwerach z 1898 r. przytoczona na podstawie tabeli znajdującej się w: J. Kudirka, op. cit., s. 68-80.

${ }^{10}$ Archiwum Państwowe w Łodzi, Łódzka Dyrekcja Szkolna (dalej: APŁ. ŁDSz.), sygn. 2083. Teczka S. Keturakisa. Świadectwo wójta gminy Freda. Godlewo - wieś i folwark, gm. Freda, przy trakcie KownoMariampol. Znajdowały się tam parafia katolicka (od 1803 r.) i ewangelicko-augsburska (od 1818 r.); SGKP, t. 2, Warszawa 1881, s. 644 .

${ }^{11}$ APŁ. ŁDSz. sygn. 2083, op. cit., zobowiązanie do zwrotu kosztów i potwierdzenie autentyczności podpisu.
} 
na przeciwległy kraniec Królestwa Polskiego, do guberni piotrkowskiej należącej do Łódzkiej Dyrekcji Szkolnej (ŁDSz). Znaleźli się w zupełnie obcym sobie środowisku, w którym dodatkowo występowała bariera językowa (w większości słabo znali oni wtedy język polski ${ }^{12}$, posługując się językiem rosyjskim, a ten był przez miejscowych chłopów postrzegany jako obcy). Duża odległość pomiędzy wioskami guberni piotrkowskiej a Litwą sprawiała, że odwiedziny w stronach rodzinnych nie były częste. Działo się tak w dużej mierze z powodu braku pieniędzy, a ściślej na skutek nie zawsze właściwej gospodarki posiadanymi kwotami ${ }^{13}$.

Lata nauki przyczyniły się także do zawiązania młodzieńczych przyjaźni. Korespondencja zachowana w zbiorach rodzinnych Stanisława Polakowskiego (jedynego Polaka w tym gronie) jest tego odbiciem. Dla historyka stanowi ważne źródło informacji. Ostatni dzień w Seminarium w Wejwerach w relacji Stanisława Polakowskiego wyglądał następująco:

19 czerwca 1898 roku ostatni raz zebraliśmy się w tzw. szkole wzorowej w Wejwerach. Absolwenci tam zajęli salę aktową, aby usłyszeć, że od tego dnia przestajemy się nazywać wychowankami III kursu, gdyż otrzymujemy patenty nauczycielskie. Po czem wieczorem były tańce, które trwały do północy, a potem poszliśmy na zbiorową ucztę koleżeńską. [...] Na drugi dzień, czy na trzeci chodziliśmy „kupą” i żegnaliśmy się z naszymi nauczycielami. Było weselej, potem rozjechali się wszyscy, aby już nie zejść się więcej ${ }^{14}$.

\section{Trudne początki... z kagankiem oświaty}

Procedurę podjęcia pierwszej w życiu pracy nauczycielskiej Stanisława Keturakisa otwiera podanie, z którym 14 czerwca 1898 r. zwrócił się do naczelnika Łódzkiej Dyrekcji Szkolnej (ŁDSz). Prosił w nim o zatrudnienie w charakterze nauczyciela szkoły elementarnej. W swej prośbie informował, że jego dyplom i wszystkie dokumenty znajdują się w kancelarii Suwalskiej Dyrekcji Szkolnej ${ }^{15}$. Zanim naczelnik ŁDSz podjął stosowną decyzję, w związku ze złożonym podaniem najpierw informował gubernatora piotrkowskiego, że zgłosił się do niego absolwent Seminarium Nauczycielskiego w Wejwerach z prośbą o posadę nauczycielską. Prosił więc „o opinię co do jego postawy politycznej”16.

12 Przypuszczenie to potwierdzają listy przywołanej grupy przyjaciół z pierwszych lat po podjęciu pracy, zachowane w prywatnym archiwum autora niniejszego tekstu. Te listy prywatne w oryginale były pisane po rosyjsku. Właśnie z ich treści wynika słaba czy też niedostateczna znajomość języka polskiego. Jak przyznają autorzy tych listów, konieczność funkcjonowania w polskim środowisku, wymuszała coraz lepsze opanowanie tego języka.

13 D. Złotkowski, op. cit. O izolacji nauczyciela na wsi kieleckiej wspominała B. Szabat, Szkolnictwo, op. cit., s. 190 .

${ }^{14}$ Archiwum prywatne D. Złotkowskiego (dalej: ApDZ), notatka Stanisława Polakowskiego z dnia 21 lipca 1908 r., sygn. 605, notatka z dnia 20 czerwca 1908 r. sygn. 606.

15 APŁ. ŁDSz. sygn. 2083, op. cit., podanie do ŁDSz o pracę.

${ }^{16}$ Ibidem, prośba do gubernatora o opinię co do postawy politycznej kandydata. 
Dopiero po zyskaniu opinii, niewątpliwie pozytywnej, 24 lipca 1898 r. naczelnik postanowił skierować Stanisława Keturakisa na posadę nauczyciela do Jednoklasowej Szkoły Elementarnej we wsi Jedlno (gmina Radziechowice, pow. noworadomski ${ }^{17}$ ), z pensją 250 rubli rocznie. I nakazał mu „odprawić się” do miejsca pobytu, a tam zwrócić się do wójta gminy Radziechowice. Polecił również, by o objęciu służby poinformować go niezwłocznie ${ }^{18}$. Po przybyciu na miejsce 14 lipca 1898 r., jednym z pierwszych dokumentów, które przyszło podpisać młodemu nauczycielowi, był odręczny tekst złożonej przysięgi na wierność carowi Mikołajowi II i następcy tronu wielkiemu księciu Jerzemu Aleksandrowiczowi. Zobowiązywał się w nim przed Bogiem „,do końca żywota i ostatniej kropli krwi” ofiarnie pracować w zawodzie nauczyciela ${ }^{19}$. Objęcie placówki oświatowej w Jedlnie odbyło się bez przeszkód. 31 lipca 1898 r. wójt gminy Radziechowice przesłał naczelnikowi ŁDSz protokół zainstalowania nauczyciela S. Keturakisa w szkole ${ }^{20}$. Sam naczelnik zatwierdził ten fakt 7 września 1898 r. $^{21}$.

Pierwszy rok pracy okazał się dla Stanisława Keturakisa wyjątkowo trudnym. 29 września 1899 r., zwracając się do Naczelnika ŁDSz, prosił o zmianę szkoły.

Tu m.in. trzy razy dziennie pali się w piecu, a temperatura nie przekracza 10 st., okna przy silnym wietrze otwierają się. Oprócz tego w klasie długości 9 arszynów, szer. 8 arszynów... mieści się 70 ludzi. Jest duszno i wilgotno. Nauczyciel i uczniowie mają trudne warunki, każdego dnia winni chorować. Swoje rzeczy muszę trzymać u sąsiadów. Raz mnie już okradli ${ }^{22}$.

Władze szkolne próbowały interweniować. Po otrzymaniu raportu co od stanu szkoły, zwróciły się 8 października 1899 r. do inspektora szkół elementarnych powiatu częstochowskiego z prośbą o poprawę warunków panujących w szkole ${ }^{23}$. Piętnastego listopada 1899 r. inspektor informował naczelnika ŁDSz, że ogrzewanie szkoły zostało

17 Jedlno - wieś i kolonia włościańska, pow. noworadomski, gm. Radziechowice, parafia Jedlno. SGKP, t. 3, Warszawa 1882. s. 549-550.

18 APŁ. ŁDSz. sygn. 2083, op. cit., delegowanie do objęcia służby. Najpełniejszym opracowaniem odnoszącym się do kwestii pensji nauczycielskich jest praca A. Smołaskiego, Uposażenie nauczycieli w Polsce. Zarys historyczny do 1939 roku, Opole 1990. O tej istotniej kwestii wspominają: także: K. Poznański, Oświata elementarna, op. cit., s. 106-107. E. Podgórska, Szkolnictwo elementarne, op. cit., s. 94-96, czy B. Szabat, Szkolnictwo początkowe, op. cit., s. 67, 174.

${ }^{19}$ APŁ. ŁDSz. sygn. 2083, op. cit., tekst przysięgi na wierność carowi. Zob. także E. Podgórska, Szkolnictwo elementarne, op. cit., s. 95 i B. Szabat, Szkolnictwo początkowe, op. cit., s. 172-173.

${ }^{20}$ APL. ŁDSz. sygn. 2083, op. cit., protokół zainstalowania S. Keturakisa.

21 APŁ. ŁDSz. sygn. 2083, op. cit., zatwierdzenie na posadzie nauczyciela.

22 APŁ. ŁDSz. sygn. 2083, op. cit., inspektor do naczelnika ŁDSz.

23 APŁ. ŁDSz. sygn. 2083, op. cit., interwencja u inspektora spowodowana listem S. Keturakisa z 23 września. Należy nadmienić, że generalnie kondycja budynków szkolnych pozostawiała wiele do życzenia. Potwierdziły to np. opracowania: Z. Kmiecik, Ruch oświatowy na wsi. Królestwo Polskie 1905-1914, Warszawa 1963. s. 8384 czy B. Szabat, Szkolnictwo poczatkowe, op. cit., s. 38-40; K. Poznański, Oświata elementarna, op. cit., s. $62-70$. 
doprowadzone do porządku na tyle, na ile było to możliwe. Nauczyciel powinien na razie zadowolić się tym, co jest. Poważny remont planowany jest na przyszły rok ${ }^{24}$. Dwa dni później S. Keturakisa, niejako na pocieszenie poinformowano, że w przyszłym roku ma się rozpocząć budowa nowej szkoły w Jedlnie ${ }^{25}$.

Młodość ma jednak swoje prawa. Ludzie zakładali rodziny. Stanisław Keturakis, pracujący wtedy w Jedlnie, 30 maja 1900 r. formalnie zwrócił się do naczelnika ŁDSz z następujacym pismem: „Proszę o pozwolenie wstąpienia w związek małżeński z panną Józefą Birsztejn mieszkającą w mieście Preny, suwalskiej guberni”" ${ }^{26}$. W odpowiedzi datowanej na 5 czerwca 1900 r., władze oświatowe stwierdziły: ,ze strony ŁDSz nie ma przeciwwskazań na zawarcie przez Was małżeństwa z Józefą Birsztejn, córką Aleksandra Birsztejna. Akt ślubu powinien być przedstawiony w kancelarii” ${ }^{27}$. Zgodnie z poleceniem, 8 lipca 1900 r. wspomniany dokument został władzom przedstawiony ${ }^{28}$.

Założenie rodziny nie wpłynęło na poprawę warunków mieszkaniowych Stanisława Keturakisa. W raporcie z 4 września 1901 r., skierowanym do naczelnika ŁDSz napisał, że mieszkanie, które zajmował, znajdowało się w takim stanie, że dalsze zamieszkiwanie w nim jest niemożliwe. Informował, że dach przecieka, a ściany pokrywa wilgoć. Dodał przy tym, że budowa nowego domu jeszcze się nie rozpoczęła, a wynająć mieszkania u chłopów nie można. Prosił więc o przeniesienie do innej szkoły ${ }^{29}$.

Pomimo trudnych warunków bytowych, rodzina wkrótce powiększyła się. 9/22 maja 1901 r. S. Keturakisowi urodził się pierwszy syn - Eugeniusz Józef (wieś Jedlno 20 czerwca/3 lipca) ${ }^{30} .1$ lipca 1901 r. nauczyciel szkoły elementarnej w Jedlnie informował o tym radosnym fakcie naczelnika $\left\lfloor D S z^{31}\right.$. Wkrótce ponownie prosił o przeniesienie do innej szkoły. Trzeciego lipca 1901 r., zwracając się do naczelnika ŁDSz, podawał następujące argumenty: od lutego ubiegłego roku do tego czasu chorował na uporczywy kaszel, stracił 1/3 mojej pensji na leczenie (19 rubli miesięcznie) i popada w długi, które mogą być spłacone tylko lepszą pensją. Odpowiedź władz z 15 lipca 1902 roku była jednak odmowna ${ }^{32}$.

${ }^{24}$ APŁ. ŁDSz. sygn. 2083, op. cit., podanie o zmianę placówki z powodu okropnych warunków.

${ }^{25}$ Ibidem, odpowiedź inspektora na list S. Keturakisa.

${ }^{26}$ Ibidem, S. Keturakis prosi o zgodę na ślub a Józefą Birsztejn. Pteny - miasto w pow. mariampolskim, gub. suwalska (w pobliżu Niemna). Miasto zaludnione przeważnie przez Żydów; SGKP, t. 9, Warszawa 1888. s. $34-35$.

${ }^{27}$ APŁ. ŁDSz. sygn. 2083, op. cit., ŁDSz zgadza się na ślub.

${ }^{28}$ Ibidem, informacja o akcie ślubu Keturakisa.

${ }^{29}$ Ibidem, podanie o S. Keturakisa o inną szkołę.

${ }^{30}$ Ibidem, akt urodzin syna S. Keturakisa, krótki życiorys spisany przez S. Keturakisa.

${ }^{31}$ Ibidem, informacja dla naczelnika $Ł D S z$ o urodzinach syna S. Keturakisa, krótki życiorys spisany przez S. Keturakisa.

${ }^{32}$ Ibidem, raport S. Keturakisa i odmowa naczelnika ŁDSz. 
Według aktu stanu cywilnego z parafii Jedlno Stanisławowi Keturakisowi, teraz nauczycielowi szkoły w Wancerzowie, lat 26, urodził się drugi syn - Zdzisław Aleksander. Według cytowanego zapisu ojciec w towarzystwie Stefana Czajczyńskiego, gminnego sekretarza IV Okręgu Sądowego, lat 35, i Aleksandra Dyjesińskiego, mstowskiego organisty, lat 29, poinformował, że syn urodził się we Mstowie 12/25 listopada 1904 r., o 12 w południe z jego żony Józefy z domu Birsztejn, lat 23. Rodzicami chrzestnymi byli Stefan Czajczyński i Julianna Wojsław ${ }^{33}$.

Warunki w placówkach, które przyszło objąć młodym nauczycielom, wielu przerosły. Piszący te słowa udowodnił to w innym artykule ${ }^{34}$. Początkowo słabo znali oni język polski (głównie biernie). Mieli przy tym świadomość, że przez polskich chłopów są postrzegani jako przedstawiciele obcej, administracji carskiej ${ }^{35}$. Ocena własnego położenia była w dużej mierze uzależniona od cech charakteru danego człowieka. Stanisław Keturakis był chyba najbardziej operatywnym z grupy przyjaciół. Jeszcze 15 lutego 1898 r. tak opisywał początki swej pracy oświatowej: „W ogóle to nie mogę narzekać, że mi się nie układa, wszystko weszło w nawyk i stało się jednostajnym tak, że myśleć o tym przestałem" 36 .

Większość z tych młodych ludzi nie chciała, czy też nie potrafiła, należycie wykorzystać źródła swych dodatkowych dochodów, które mogła dać uprawa przysługującego im kawałka ziemi ${ }^{37}$. Stanisław Keturakis w grudniu 1900 r., tak opisywał swe rolnicze zajęcia:

Próbuję zająć się uprawą roli. Posadziłem 3 korce [294,5 kg - D.Z.] kartofli i jeszcze zasieję $1 / 2$ korca [24,5 kg - D.Z.] gryki i $1 / 2$ korca [49,1 kg - D.Z.] łubinu. Niedługo zacznę kopać torf, nakopię chyba 20 fur, to wystarczy na cały rok. Bardzo drogo mnie to wszystko kosztuje i w swoje pole włożyłem około 18 rubli, nie licząc nawozu 16 wozów, a jeszcze torf - do niego trzeba wziąć 5 ludzi na dwa dni. Czort wie, opłaci mi się to, czy nie ${ }^{38}$.

Stanisław Keturakis urodzony w Godlewie 22 kwietnia 1879 r., po ukończeniu Seminarium Nauczycielskiego w Wejwerach k. Kowna (1898 r.), jak inni został skierowany do pracy w szkołach na terenie guberni piotrkowskiej. Od 1 lipca 1898 r. do 1 listopada 1901 r. był nauczycielem wiejskiej Szkoły Elementarnej w Jedlnie, pow.

${ }^{33}$ Archiwum Państwowe w Częstochowie (dalej: APCz.), ASC Mstów 1904, akt nr 340. APŁ. ŁDSz. sygn. 2083, op. cit., akt uroczenia syna Zdzisława Aleksandra, Mstów 12/25 listopada 1904 r., rodzice Stanisław i Józefa Birsztein.

34 D. Złotkowski, Obraz szkoły wiejskiej schyłku XIX wieku w relacjach młodych nauczycieli, w: Rodzinne i pozarodzinne środowiska wychowawcze. Szkice historyczno-pedagogiczne, red. A. Siedlaczek-Szwed, I. Wagner, Wydaw. Wyższej Szkoły Pedagogicznej, Częstochowa 2002.

35 Ibidem, s. 66.

${ }^{36}$ Ibidem. Zob. List S. Keturakisa do S. Polakowskiego, dat. Kołduny 15 listopada 1898 r., sygn. 102.

${ }^{37}$ O zagadnieniu tym w odniesieniu do Kielc pisała B. Szabat, Szkołnictwo poczatkowe, op. cit. s. $178-181$.

38 D. Złotkowski, Obraz szkoły wiejskiej, op. cit., s. 74. Zob. List S. Keturakisa do S. Polakowskiego, dat. m-ce (?) 14 czerwca 1900 r., sygn. 315. Najpełniej kwestię działek szkolnych poruszył K. Poznański, Oświata elementarna, op. cit., s. 61-62. 
noworadomski (z pensją 250 rubli rocznie) ${ }^{39}$. W $1901 \mathrm{r}$. przeniesiono go na posadę nauczyciela w Szkole Elementarnej we Mstowie, pow. częstochowski (z pensją 200 rubli). Pracował tam od 1 listopada 1901 r. do 15 stycznia 1904 r. ${ }^{40}$. Od 15 stycznia 1904 r. do 15 października 1905 r. nauczał w wiejskiej Szkole Elementarnej w Wancerzowie, pow. częstochowski (z pensją 300 rubli rocznie) ${ }^{41}$. Od 15 października 1905 r. do 1 listopada 1907 r. ponownie zatrudniono go w szkole w Jedlnie (z pensją 250 rubli) ${ }^{42}$. Wyraźnym awansem, zarówno pod względem materialnym, jak i prestiżowym, było mianowanie go 1 listopada 1907 r. starszym nauczycielem Michajłowskiej Szkoły Elementarnej w Zagórzu (z pensją 360 rubli rocznie) ${ }^{43}$. Powyższy przebieg służby potwierdzają kolejne jej opisy: z 1911 r. ${ }^{44}$ i z lutego 1912 r. ${ }^{45}$. Pomimo dobrej oceny S. Keturakis, starszy nauczyciel szkoły w Zagórzu, 18 lipca 1913 r. w piśmie do naczelnika ŁDSz zauważył, „że nie został jeszcze nagrodzony Medalem za trudy pracy nauczycielskiej”46.

Zachowany materiał archiwalny pozwala przynajmniej częściowo (w zakresie liczby uczniów) zrekonstruować obraz wiejskich szkół elementarnych, w których pracował Stanisław Keturakis. I tak według raportu z grudnia 1903 r., po wizytacji stwierdzono:

Tabela 1. Stan uczniów szkoły we Mstowie, 5 grudnia 1903 r.

\begin{tabular}{|l|l|l|}
\hline & \multicolumn{1}{|c|}{ Zapisanych } & \multicolumn{1}{c|}{ Obecnych } \\
\hline I oddział & 14 chłopców, 7 dziewczynek & 14 chłopców, 7 dziewczynek \\
\hline II oddział & 8 chłopców, 0 dziewczynek & 7 chłopców, 0 dziewczynek \\
\hline III oddział & 2 chłopców, 1 dziewczynka & 2 chłopców, 1 dziewczynka \\
\hline Razem uczniów & 32 uczniów & 31 uczniów \\
\hline
\end{tabular}

Źródło: APŁ, ŁDSz, sygn. 2083. Teczka S. Keturakisa, 047-047 jpg. Raport z wizytacji szkoły.

39 APŁ. ŁDSz. sygn. 2083, op. cit., formularz przebiegu służby z 1907 r.

${ }^{40}$ Ibidem; Mstów - osada miejska (do 1867 r. miasteczko nad rzeką Wartą, pow. częstochowski, gm. Wancerzów, parafia Mstów. Położony przy trakcie Częstochowa-Koniecpol. SGKP, t. VI, Warszawa 1885. s. 779.

${ }^{41}$ APŁ. ŁDSz. sygn. 2083, op. cit., naczelnik ŁDSz przenosi S. Keturakisa na posadę nauczyciela Mstowskiej Szkoły Elementarnej z dniem 15 stycznia 1904 r.; Wancerzów - wieś, folwark i osada młyńska nad rzeką Wartą, pow. częstochowski, gm. Wancerzów, parafia Mstów. Ok. 1892 r. wieś liczyła 28 domostwa, 220 mieszkańców, folwark 6 domostw, 65 mieszkańców. SGKP, t. XII, Warszawa 1892. s. 934.

${ }^{42}$ APŁ. ŁDSz., sygn. 2083. op. cit., krótki życiorys spisany przez S. Keturakisa; ibidem, naczelnik ŁDSz przenosi S. Keturakisa z dniem 15 października 1905 r. na posadę nauczyciela do Jedlneńskiej Szkoły Elementarnej z pensją 250 rubli rocznie.

${ }^{43}$ Ibidem, formularz przebiegu służby; Zagórze - wieś i folwark nad rzeką Okszą, pow. częstochowski, gm. Kamyk, parafia Kłobuck. Położona kilkanaście km na północny zachód od Częstochowy. Ok. 1895 r. wieś liczyła 44 domostwa, 490 mieszkańców, a folwark 10 domostw, 50 mieszkańców. SGKP, t. XIV, Warszawa 1895. s. 264-265.

${ }^{44}$ APŁ. ŁDSz. sygn. 2083, op. cit., informacja o przebiegu pracy S. Keturakisa z 1911 r.

${ }^{45}$ Ibidem, formularz przebiegu służby z lutego 1912 r.(?), życiorys S. Keturakisa.

${ }^{46}$ Ibidem, pismo do naczelnika ŁDSz. 
Tabela 2. Stan uczniów szkoły w Jedlnie, 6 marca 1906 r.

\begin{tabular}{|l|l|l|}
\hline & \multicolumn{1}{|c|}{ Zapisanych } & \multicolumn{1}{c|}{ Obecnych } \\
\hline Wstępny oddział & 54 chłopców, 33 dziewczynki & 39 chłopców, 24 dziewczynki \\
\hline I oddział & 20 chłopców, 11 dziewczynek & 13 chłopców, 11 dziewczynek \\
\hline II oddział & 5 chłopców, 0 dziewczynek & 3 chłopców, 0 dziewczynek \\
\hline Razem uczniów & 123 uczniów & 90 uczniów \\
\hline
\end{tabular}

Źródło: APŁ, ŁDSz, sygn. 2083. Teczka S. Keturakisa, 094 jpg. Raport o szkole S. Keturakisa.

Tabela 3. Stan uczniów szkoły w Jedlnie, 10 listopada 1906 r.

\begin{tabular}{|l|l|l|}
\hline & \multicolumn{1}{|c|}{ Zapisanych } & \multicolumn{1}{c|}{ Obecnych } \\
\hline Wstępny oddział & 40 chłopców, 32 dziewczynki & 25 chłopców, 20 dziewczynek \\
\hline I oddział & 27 chłopców, 16 dziewczynek & 24 chłopców, 16 dziewczynek \\
\hline II oddział & 7 chłopców, 3 dziewczynki & 6 chłopców, 2 dziewczynki \\
\hline III oddział & 5 chłopców, 1 dziewczynka & 5 chłopców, 1 dziewczynka \\
\hline Razem uczniów & 131 uczniów & 99 uczniów \\
\hline
\end{tabular}

Źródło: APŁ. ŁDSz. sygn. 2083. Teczka S. Keturakisa. 099-100 jpg. Raport o szkole S. Keturakisa.

Tabela 4: Stan uczniów szkoły w Zagórzu, 7 grudnia 1907 r.

\begin{tabular}{|l|l|l|}
\hline & \multicolumn{1}{|c|}{ Zapisanych } & \multicolumn{1}{c|}{ Obecnych } \\
\hline Wstępny oddział & 37 chłopców, 20 dziewczynek & 30 chłopców, 26 dziewczynek \\
\hline I oddział & 30 chłopców, 15 dziewczynek & 30 chłopców, 15 dziewczynek \\
\hline II oddział & 6 chłopców, 1 dziewczynka & 6 chłopców, 1 dziewczynka \\
\hline III oddział & 1 chłopiec, 0 dziewczynek, & 1 chłopiec, 0 dziewczynek, \\
\hline Razem uczniów & 110 uczniów & 109 uczniów \\
\hline
\end{tabular}

Źródło: APŁ. ŁDSz. sygn. 2083. Teczka S. Keturakisa. 106- jpg. Protokół z wizytacji szkoły w Zagórzu przez inspektora $\mathrm{z}$ dnia 1 grudnia $1907 \mathrm{r}$.

Tabela 5: Stan uczniów szkoły w Zagórzu, 22 marca 1911 r.

\begin{tabular}{|l|l|l|}
\hline & \multicolumn{1}{|c|}{ Zapisanych } & \multicolumn{1}{c|}{ Obecnych } \\
\hline I oddział & 38 chłopców, 25 dziewczynek, & 26 chłopców, 14 dziewczynek \\
\hline II oddział & 25 chłopców, 7 dziewczynek, & 18 chłopców, 4 dziewczynki \\
\hline III oddział & 6 chłopców, 2 dziewczynki & 6 chłopców, 1 dziewczynka \\
\hline Razem uczniów & 103 uczniów & 69 uczniów \\
\hline
\end{tabular}

Źródło: APŁ. ŁDSz. sygn. 2083, op. cit., protokół z wizytacji szkoły w Zagórzu. 
Ważnym elementem pracy nauczycielskiej były wakacje, kiedy to istniała możliwość wyjazdu w rodzinne strony. Formalnie nauka w szkołach wiejskich powinna rozpoczynać się 14 października, a kończyć 1 czerwca. W praktyce nauczyciel rozpoczynał zajęcia dopiero wtedy, gdy dzieci zaczynały uczęszczać do szkoły. Większość uczniów zwykle przychodziła do szkoły po zakończeniu robót w polu, z nastaniem przymrozków, a opuszczała szkołę wczesną wiosną, z rozpoczęciem okresu ,pasionki” krów”. Według zasady obowiązującej do I wojny światowej lekcje powinny odbywać się w godzinach od 8 do 11 i od 14 do $18^{47}$. Korespondencja pomiędzy absolwentami Seminarium Nauczycielskiego w Wejwerach z pierwszych lat pracy sytuację tę potwierdzała. Juozas Jasaitis w liście z 26 sierpnia 1898 r. z Rzeczycy pisał: „Latem 1898 roku przybyłem do szkoły, złożywszy przysięgę przed ołtarzem carów. [...] Lekcje w szkole zacznę od listopada, a skończę w początkach kwietnia. [...]. Czasu wolnego mam dosyć, nie wiem nawet, co z nim zrobić"48.

B. Szabat zwróciła uwagę, że

urlop na czas wakacji zależał także od wójta gminy, który wyrażał zgodę na wyjazd nauczyciela ze wsi. Dodatkowo, musiał wyrazić zgodę naczelnik Dyrekcji. Dotyczyło to także wyjazdu na święta. Gdyby nauczyciel wyjechał bez wymaganych zezwoleń, groziła mu kara aż do zwolnienia włącznie ${ }^{49}$.

Niestety, niewiele wiadomo o tym, gdzie i jak swe wakacje spędzał Stanisław Keturakis. W pierwszych latach kariery nauczycielskiej jeździł zapewne w rodzinne strony do Godlewa, gdzie mieszkał jego ojciec. Znaleziono tylko dwa ślady dotyczące tych wyjazdów wakacyjnych. Pierwszy to zapytanie skierowane 17 maja 1903 r. do naczelnika ŁDSz: „wobec zmiany przepisów, pytam, kto ma mi wydać zgodę na wyjazd wakacyjny do guberni suwalskiej? ${ }^{50}$. W rodzinnych stronach bywał zapewne już wcześniej. Stamtąd pochodziła bowiem jego żona - Józefa Birsztejn. Bardzo możliwe, że zawarto tam ślub. Nie sposób także odpowiedzieć, czy na wakacje wyjeżdżał tam z małymi dziećmi. Drugi list pochodził z tego tego samego roku. Keturakis pisał w nim: „Mam honor poinformować Waszą Wysokość, że przybyłem z odpoczynku 15 sierpnia i podjąłem pracę"51.

Kontakty, które utrzymywał z kolegami z seminarium, pozwalają zwrócić uwagę, że miał umysł otwarty, śledził ich kariery. Prawdopodobnie niewielu z nich wytrwało

${ }^{47}$ Z. Kmiecik, op. cit., s. 100-102. K. Poznański, op. cit., s. 129; B. Szabat, Szkolnictwo początkowe, op. cit, s. 24. Por. K. Konarski, Dzieje szkolnictwa w b. Królestwie Kongresowym 19151918, Kraków 1923, s. 187.

${ }^{48}$ ApDZ., List J. Jasaitisa do S. Polakowskiego, Rzeczyca, 26 sierpnia 1898, sygn. 104. D. Złotkowski, Życie, op. cit., s. 23.

49 B. Szabat, Szkolnictwo początkowe, op. cit., s. 189; E. Podgórska, Poglądy chłopów na funkcję szkoły w drugiej połowie XIX wieku na przykładzie Łaznowa, „Zeszyty Naukowe Uniwersytetu Łódzkiego” 1969, z. 61, s. 75 (o roli wójta); J. Lipiec, Materialy do dziejów szkolnictwa i oświaty ludowej w okręgu częstochowskim u schyłku XIX wieku „Ziemia Częstochowska” 1965, t. V, s. 90-94.

${ }^{50}$ APŁ. ŁDSz. sygn. 2083, op. cit., S. Keturakis pyta, kto mu udzieli zgody na wakacyjny wyjazd.

${ }^{51}$ Ibidem, S. Keturakis wraca z urlopu. 
na posadzie nauczyciela. Poszukiwali innych zawodów. Ostatnie dziesięciolecie XIX w. to czas spokojny. Stąd np. pozycja materialna zawodowego wojskowego była dla nich bardzo nęcąca. Jednym z tych, którzy wybrali taką właśnie drogę, był Edmund Kessler. W okresie 1 lipca 1898 r.-1 października 1899 r. pracował on w szkole w Kołdunach. Następnie porzucił profesję nauczycielską i wstąpił do 111 Dońskiego Pułku Piechoty, stacjonującego w Mariampolu, z nadzieją dalszego kształcenia się w wojsku"s2. Stanisław Keturakis tak pisał o tym fakcie: „Edmund Kessler już drugi rok jest podporucznikiem. Służy w Kownie i bierze 70 rubli miesięcznie. Od nowego roku ma zamiar przejść do straży pogranicznej do będzińskiego powiatu na pensję 150 rubli miesięcznie"s3. Przy wynagrodzeniu nauczycielskim wynoszącym 200-250 rubli rocznie(!) trudno się dziwić porzucaniu zawodu nauczycielskiego ${ }^{54}$.

Pewną korzyścią dla nauczyciela było zapewne, że profesja ta zwolniała ze służby wojskowej. Kolega S. Keturakisa Stanisław Polakowski doświadczył tego dobrodziejstwa. Było to istotne szczególnie w obliczu wojny rosyjsko-japońskiej 1904-1905. 21 stycznia 1905 r. otrzymał on pismo o treści: „Wójt gminy Zamoście prosi Was Miłościwy Panie o niezawodne przybycie jutro, o 10 rano, do gminnego urzędu z zaświadczeniem, że Pan jako nauczyciel nie podlega do służby wojskowej, ponieważ takie zaświadczenie jest mi niezbędne dla poinformowania kierownika powiatu"55. W tym przypadku zawód nauczyciela uchronił przed mobilizacją i wojną w dalekiej Mandżurii ${ }^{56}$.

\section{Szkoła w Zagórzu}

Ostatni znany etap pracy zawodowej Stanisława Keturakisa to praca w szkole w Zagórzu. Był tam zatrudniony już jako starszy nauczyciel (tj. dyrektor szkoły). Pracował tam od 1 listopada 1907 r. najprawdopodobniej do lata 1914 r. ${ }^{57}$. Nauczał języka rosyjskiego, polskiego, arytmetyki, historii oraz geografii ${ }^{58}$. Zachowany materiał źródłowy wskazuje, że miał powołanie, a przy tym cechowała go operatywność. Potrafił wykorzystać wszelkie nadążające się możliwości.

Pierwszym śladem działan, które miały doprowadzić do utworzenia w Zagórzu - centrum dóbr Ostrowy, jednoklasowej Michajłowskiej Szkoły Elementarnej był list Głównego

52 D. Złotkowski, Obraz szkoły, op. cit., s. 75; Zob. APŁ. ŁDSz., teczka personalna E. Kesslera, sygn. 2080.

53 APŁ, ŁDS, Teczka personalna E. Kesslera, sygn. 2080.

${ }^{54}$ D. Złotkowski, Obraz szkoły, op. cit., s. 75; Zob. List S. Keturakisa do S. Polakowskiego, dat. Godlewo 25 sierpnia 1906 r., sygn. 308.

55 D. Złotkowski, Obraz szkoły, op. cit., s. 74-75.

${ }^{56}$ D. Złotkowski, Obraz szkoły, op. cit., s. 7576. Zob. Urzędowe zawiadomienie S. Polakowskiego, ,że jako nauczyciel nie podlega służbie wojskowej”. 25 stycznia 1905 r., sygn. 510.

${ }^{57}$ APŁ. ŁDSz., op. cit., krótki życiorys spisany przez S. Keturakisa.

${ }^{58}$ Ibidem. 
Zarządcy tych dóbr, Walentego Telesforowicza Szackiego do naczelnika ŁDSz 29 sierpnia 1907 r. ${ }^{59}$. Kolejne pismo w tej sprawie miało datę 7 września 1907 r. Zarządca dóbr powoływał się tu na bliżej niesprecyzowane uzgodnienia $\mathrm{z}$ gubernatorem piotrkowskim ${ }^{60}$.

Interesujący jest obraz szkoły z początkowego etapu jej istnienia uwidoczniony w etacie placówki pochodzącym z początku września $1907 \mathrm{r}$.

Przychód:

na utrzymanie szkoły ze środków dóbr przeznacza się 605 rubli, szkoła znajduje się w specjalnie zbudowanym domu, ogrzewanie zapewnią dobra, nauczycielowi przynależy przydomowy ogród.

Rozchód:

1) na roczne wynagrodzenie nauczyciela 360 rubli,

2) na zapewnienie ubezpieczenia budynku od ognia 120 rubli,

3) na nagrody dla uczęszczających uczniów 50 rubli,

4) na książki dla biednych uczniów 25 rubli,

5) na bibliotekę i pomoce naukowe 25 rubli,

6) do dyspozycji dyr. na rozchody dla nauczyciela 25 rubli. RAZEM 605 rubli.

Budżet szkoły zamykał się w kwocie 605 rubli. Obowiązywał od 1 września 1907 r. i był poddany akceptacji zarówno buchaltera z Zarządu Dóbr „Ostrowy”, jak i naczelnika $Ł D S z^{61}$. Władze oświatowe, którym miała podlegać nowo tworzona placówka szkolna, musiały tu działać bez zbędnej zwłoki. Zarząd dóbr kilkakrotnie zwracał się do naczelnika ŁDSz, prosząc o odpowiedź, „na jakim etapie są starania o otwarcie szkoły początkowej we wsi Zagórze i mianowanie nauczyciela"62.

Sprawy nie należało opóźniać przede wszystkim ze względu na osobę patrona, jak byśmy dziś powiedzieli fundatora szkoły, wszak był nim wielki książę Michał Aleksandrowicz Romanow - brat ówczesnego cara Rosji, potencjalnie jego następca. Odmowa byłaby niewskazana także z tego powodu, że to zarząd dóbr brał na siebie większość kosztów funkcjonowania szkoły i utrzymania nauczyciela. W. Szacki w liście z 8 października 1907 r., skierowanym do naczelnika ŁDSz., prosił ,aby szkoła była skarbową ze wszystkimi prawami przeznaczonymi dla takiej szkoły" i powtarzał wcześniejsze zobowiązanie, że „szkoła będzie zabezpieczona środkami dóbr Ostrowy”. Ponadto do rozporządzenia dyrekcji na drobne wydatki każdego roku przeznaczano po 25 rubli. Do szkoły miały chodzić dzieci służby folwarcznej, a przy wolnych miejscach przyjmowano dzieci chłopskich ze wsi Zagórze. Nauka była dla wszystkich bezpłatna. Starano

59 APŁ. ŁDSz. sygn. 1438. O Michałowskiej szkole początkowej w dobrach Ostrowy. List Głównego Zarządcy dóbr Walentego Telesforowicza Szackiego skierowany do naczelnika ŁDSz. z 29 sierpnia 1907 r.

${ }^{60}$ Ibidem, list W.T. Szackiego do naczelnika ŁDSz. z 7 września 1907 r.

${ }^{61}$ Ibidem, budżet szkoły od 1 września 1907 r.

${ }^{62}$ Ibidem, pismo zarządu dóbr do naczelnika ŁDSz. 
się, by szkoła miała „przydany rolniczy charakter” i dlatego „dzieciom służyć będzie sad, oranżeria i ogród"63.

Wskazano także obsadę personalną szkoły. Oprócz nauczyciela do grona wykładowców zaliczono: ks. kanonika Puacza - nauka religii (z polecenia władz kościelnych od 13 grudnia 1907 r. religii nauczał ksiądz Wojciechowski); przyrody i higieny miał nauczać doktor majątku G. Brzozowski; ,,pszczelnictwo” miało pozostawać w gestii pomocnika buchaltera majątku Gomoliszewskiego. Praktycznym nauczaniem ogrodnictwa i sadownictwa miał się zająć - ogrodnik majątku Janisewicz(? $)^{64}$. Z racji edukacyjnego charakteru otwieranej placówki, kluczową była sprawa zatrudnienia nauczyciela. Niestety, niewiele wiemy o zabiegach w tym kierunku podjętych przez głównego zarządcę dóbr Ostrowy W.T. Szackiego. Nie można wykluczyć inicjatywy samego Stanisława Keturakisa.

Władze Łódzkiej Dyrekcji Szkolnej, działając na mocy prawa z 11 września 1864 r. o szkołach elementarnych w Królestwie Polskim ${ }^{65}, 31$ października 1907 r. postanowiły w charakterze pierwszego nauczyciela jednoklasowej szkoły elementarnej w Zagórzu zatrudnić wspomnianego S. Keturakisa. Miało to nastąpić 1 listopada 1907 r. ${ }^{66}$. Kwestię zatrudnienia drugiego nauczyciela odłożono na później. Naczelnik ŁDSz prosił jedynie o dopełnienie formalności, tj. dostarczenie tekstu przysięgi i protokołu wprowadzenia nauczyciela na posadę ${ }^{67}$. Formalnie załatwiono także sprawę wynagrodzenia nauczyciela i odprowadzenie składki emerytalnej. Pensja nauczyciela w majątku Zagórze wynosiła 360 rubli rocznie, z mieszkaniem, ogrzewaniem i oświetleniem. Naczelnik ŁDSz informował jednocześnie, że zatrudniany nauczyciel ma opłacać 6\% składki na emeryturę, zgodnie z przepisami Królestwa Polskiego (20 rb. po 7 rb. 20 kop rocznie lub 60 kop. miesięcznie) $)^{68}$.

Nowo uruchomiona szkoła w Zagórzu przynajmniej formalnie musiała być oceniona przez inspektora szkolnego powiatu częstochowskiego. Wizytacja szkoły miała miejsce 1 grudnia 1907 r. Inspektor napisał, że formalnie szkoła istniała od 1 listopada 1907 r., a nauka rozpoczęła się 26 listopada. Szkoła w Zagórzu rozwijała się prawidłowo. Po zakończeniu pierwszego roku istnienia, zarząd dóbr Ostrowy 9 lipca 1908 r. informował inspektora wiejskich szkół elementarnych w powiecie częstochowskim, że w nowo otwartej placówce istnieje konieczność zatrudnienia młodszego nauczyciela. Liczba uczęszczających dzieci dochodziła do 120 ludzi. Przyznano, że co prawda przy otwarciu szkoły zarząd dóbr Ostrowy zobowiązał się do utrzymania jednego nauczyciela, ale

\footnotetext{
${ }^{63}$ Ibidem, list Zarządu dóbr z 8 października 1907 r. do naczelnika ŁDSz.

${ }^{64}$ Ibidem, obsada personalna szkoły z 1907 r.

65 S. Araszkiewicz, op. cit. Zob. także E. Podgórska, Szkolnictwo elementarne, op. cit., s. 72-74.

${ }^{66}$ APŁ. ŁDSz. sygn. 1438, op. cit., decyzja ŁDSz. z 31 października 1907 r. o zatrudnieniu w Zagórzu
} S. Keturakisa.

${ }^{67}$ APŁ. ŁDSz. sygn. 1438, op. cit., pismo naczelnika ŁDSz. z 1907 r.

${ }^{68}$ Ibidem. Zob. A. Smołaski, op. cit., s. 74-81. Por. także: B. Szabat, Szkolnictwo początkowe, op. cit., S. $178-185$. 
zatrudnienie drugiego sprawiłoby miejsce „tak dla dzieci służby, jak i tych ze wsi”. Ze strony władz oświatowych oczekiwano jedynie formalnej zgody ${ }^{69}$.

Postulowano, by zatrudnionego Stanisława Keturakisa mianowano starszym nauczycielem „na pełnym utrzymaniu dóbr”. W charakterze młodszego nauczyciela zarząd proponował zatrudnić nauczycielkę Krzepickiej Szkoły Elementarnej z gminy Wancerzów - Julię Wojsław. Zapewniano jej osobne mieszkanie, ogrzewanie i utrzymanie, tak jak we wszystkich szkołach początkowych ${ }^{70}$.

Zachowana korespondencji pomiędzy zarządem dóbr a władzami oświatowymi pozwala odtworzyć (niepełną) listę młodszych nauczycieli pracujących w Zagórzu w latach1907-1914. I tak byli wśród nich: Kazimierz Peche (15 listopada 1908-?) ${ }^{71}$, Kazimierz Bilski (1 sierpnia 1910-15 kwietnia 1911) ${ }^{72}$, Lidia Zajcew - córka buchaltera dóbr Ostrowy ${ }^{73}$, Henryk Witkowski ${ }^{74}$. Wśród osób, które ostatecznie nie objęły tej posady należy wymienić 1) Katarzynę Gercziu ${ }^{75}$, 2) Jerzego Kisielewskiego ${ }^{76}$ i 3) Adama Piechockiego ${ }^{77}$.

Współcześni opisywanym wydarzeniom mieli świadomość roli, jaką w utworzeniu i uruchomieniu szkoły w Zagórzu odegrał Walenty Szacki. W liście do naczelnika ŁDSz. z 10 lipca 1908 r. napisano: „mam honor poinformować, że projekt jest uzgodniony we wszystkich punktach z Panem Szackim. Otwarcie szkoły w majątku Zagórze to dzieło Szackiego, to on kosztem ogromnych środków, które uzyskał od wielkiego księcia"78. Szkoła była wspierana drobnymi kwotami także przez wielkiego księcia Michała. Przykładowo 10 stycznia 1909 r. starszy nauczyciel Stanisław Keturakis w swym raporcie, pisanym na maszynie na papierze z nadrukiem ,nauczyciel dóbr”, do naczelnika ŁDS stwierdzał, że

Jego Imperatorska Wysokość Wielki Książę Michał Aleksandrowicz zezwolił przeznaczyć dla prowadzonej przeze mnie szkoły elementarnej następujące książki: [wymieniono 20 pozycji D.Z.]. Proszę Waszą Wysokość o pozwolenie wpisania tych książek do Księgi Inwentarzowej ${ }^{79}$.

${ }^{69}$ APŁ. ŁDSz. sygn. 1438, op. cit.; świadczy o tym m.in. korespondencja Zarządu dóbr z władzami szkolnymi np.: 18 lipca 1908 r., 20 sierpnia 1908 r., 13 sierpnia 1908 r., 12 września 1908 r., 2 kwietnia 1909 r.; 10 lutego $1910 \mathrm{r}$.

${ }^{70}$ Ibidem, pismo zarządu dóbr do naczelnika ŁDSz.

${ }^{71}$ Ibidem, korespondencja pomiędzy zarządem dóbr a naczelnikiem $Ł D S z$.

72 APŁ. ŁDSz. sygn. 1438. O Michałowskiej Szkole Elementarnej w dobrach Ostrowy.

73 APŁ. ŁDSz. sygn. 1438, op. cit.; APŁ. ŁDSz. sygn. 2083, op. cit., informacja o 7 klasach, które ukończyła Lidia Zajcewa.

74 APE. ŁDSz. sygn. 1438, op. cit.

${ }^{75}$ Ibidem.

${ }^{76}$ Ibidem.

${ }^{77}$ Ibidem.

${ }^{78}$ Ibidem.

${ }^{79}$ Ibidem. 
Podziału uczącej się dziatwy na oddziały dokonał nauczyciel S. Keturakis. Wszystkich dzieci było 120, w tym prawosławnych 2, a katolików 118. Szkolna biblioteka dysponowała 35 książkami. Rocznie przeznaczono na nią 25 rubli. Szkolnych ławek wymieniono 12. Szkoła posiadała dwie klasy. Jedna była obszerna, druga ciasna. Jak zauważył inspektor, „uczniowie odpowiadali poprawnie i dobrze” i co ważne „przy [...] wizytacji asystował Główny Zarządca dóbr Ostrowy W.T. Szacki" ${ }^{\text {80 }}$. Raport przygotowano po wizytacji datowanej na 22 marca 1911 r., kiedy to w szkole przebywał inspektor rejonu częstochowskiego D. Czystilin ${ }^{81}$. W szkole pracował już wtedy drugi nauczyciel K. Bilski. Wykłady prowadzono według przedmiotów. W raporcie zauważono m.in. „Historia S. Keturakis doprowadzone do Katarzyny Wielkiej - dobrze. Geografia p. Keturakis. Prace pisemne w porządku. W młodszym oddziale dzieci piszą swobodnie. Dyktando wypadło pozytywnie. Dzieci śpiewały rosyjskie i polskie pieśni”. W sprawozdaniu ponownie podkreślono ogromne zasługi zarządcy dóbr Walentego Telesforowicza Szackiego. Zauważono ponadto, że „dostarcza on wszystkiego, czego szkole potrzeba. Dzieci uczą się pszczelnictwa, sadownictwa, wkrótce będą się uczyć wyplatania koszy. Ta szkoła to dar wielkiego księcia Michała Aleksandrowicza. Dzieci miały do dyspozycji: bibliotekę, gabinet fizyczny. Dokumentacja szkoły była w porządku" 82 .

Znamienne, że maszynopis kolejnego raportu z wizytacji szkoły w dniu 17 maja 1911 r. był równie pozytywny jak poprzedni. Zarząd dóbr Ostrowy (na druku firmowym) przekazał go naczelnikowi ŁDSz. Inspektor szkół elementarnych Dmitry Czystilin napisał w nim: ,z zadowoleniem przyjąłem wypowiedzi i oceny uczniów, szczególnie dobrze po rosyjsku. Bardzo za to dziękuję" $" 83$.

Stanisław Keturakis w zarządzie dóbr musiał zajmować pozycję szczególną. Posiadał papier listowy z nadrukiem: „Pieczęć nauczyciela dóbr”. W korespondencji z zwierzchnimi władzami oświatowymi posługiwał się maszyną do pisania. Ponadto w jednym z raportów napisał:

znajdujące się w użyciu dzienniki klasowe służą do zapisywania uczących się w klasie uczniów i dlatego zgodnie z ich przeznaczaniem nie mogę wykonywać cyrkularza Waszej Wysokości z 9 lutego tego roku za numerem 2115 wprowadzającym na uczących obowiązek zapisywania streszczenia każdej odbytej lekcji i określania sukcesów uczniów.

Dlatego prosił o wysłanie do szkoły dziennika ,zgodnego z prawem”\$4.

\footnotetext{
${ }^{80}$ APŁ. ŁDSz. sygn. 2083, op. cit., protokół zdawczo-odbiorczy, przy przejściu S. Keturakisa ze wsi Jedlno do Zagórza.

${ }^{81}$ Ibidem, informacja o przesłaniu raportu z wizytacji szkoły w Zagórzu z 22 marca 1911 r.

${ }^{82}$ Ibidem, protokół z wizytacji szkoły w Zagórzu.

83 Ibidem, informacja o wizytacji szkoły w Zagórzu.

${ }^{84}$ APŁ. ŁDSz. sygn. 1438., op. cit., list S. Keturakisa do naczelnika ŁDSz. z prośbą o wykładnię prawną.
} 
Znacząca pozycja S. Keturakisa, będącego już starszym nauczycielem, w Zagórzu musiała budzić zazdrość. Czy tylko jej wyrazem była zawartość teczki personalnej? 29 lutego 1912 r. musiał on złożyć oświadczenie, że nie należy do żadnych tajnych stowarzyszeń $^{85}$. A pod datą 31 marca 1912 r. wójt gminy Freda, pow. Mariampol, gubernia suwalska, musiał wystawić pismo, w którym zaświadczył, że Stanisław Matwiejewicz Keturakis jest pochodzenia chłopskiego ${ }^{86}$.

Szkoła elementarna w Zagórzu była rzeczywiście przedmiotem szczególnej troski głównego zarządcy dóbr Ostrowy W.T. Szackiego. Zwłaszcza po budowie tzw. „domu Księcia" w Częstochowie, znacznie zwiększającego dochody płynące z dóbr Wielkiego Księcia Michała Aleksandrowicza Romanowa, jego pozycja jeszcze bardziej się wzmocnieniła. Od 1913 r. zarządzał on już wszystkimi trzema majątkami ziemskimi wielkiego księcia ${ }^{87}$.

Etat Michajłowskiej Jednoklasowej Szkoły Elementarnej w Zagórzu z 1 stycznia 1913 r. wyglądał następująco.

W rubryce „przychód” napisano:

na utrzymanie szkoły rocznie wydaje się

ze środków dóbr 940 rb.

ze Skarbu Państwa 360 rb.

razem $1300 \mathrm{rb}$

W rubryce „adnotacja” napisano:

Szkoła mieści się w specjalnie zbudowanym dla niej domu, remont i ubezpieczenia od ognia należą do obowiązków Zarządu dóbr. Ogrzewanie i oświetlenie pomieszczeń szkoły i mieszkań nauczyciela wydaje się w naturze.

Do szkoły przynależy niewielki ogród.

Wykładowcy religii, pszczelnictwa i muzyki otrzymują od Zarządu dóbr osobne wynagrodzenie.

W rubryce „rozchód” napisano:

1) Na utrzymanie nauczycieli, przy gotowym mieszkaniu z ogrzewaniem i oświetleniem,

a) starszemu nauczycielowi 600 rubli

b) młodszemu nauczycielowi 500 rubli

2) na pensje stróża 144 ruble

3) na nagrody uczącym się 25 rubli

4) na bibliotekę i pomoce naukowe 25 rubli

5) w dyspozycji Dyrekcji Nauk. na nieprzewidziane wydatki szkoły 6 rubli.

RAZEM 1300 rubli $^{88}$.

${ }^{85}$ APL. ŁDSz. sygn. 2083, op. cit., oświadczenie S. Keturakisa. O kwestii tej wspomina także B. Szabat, Szkolnictwo poczatkowe, op. cit., s. 173.

${ }^{86}$ APŁ. ŁDSz. sygn. 2083, op. cit., zaświadczenie od wójta gminy Freda spod Mariampola.

${ }^{87}$ D. Złotkowski, Gospodarka w „Dominium Kłobuckim” w XIX i na początku XX wieku, TAURUS Agencja Wydawniczo-Promocyjno-Reklamowa, Radomsko 2018, s. 59-60, 144.

${ }^{88}$ APŁ. ŁDSz. sygn. 1438, op. cit., etat Michajłowskiej Jednoklasowej Szkoły Elementarnej w Zagórzu z 1 stycznia 1913 r. 


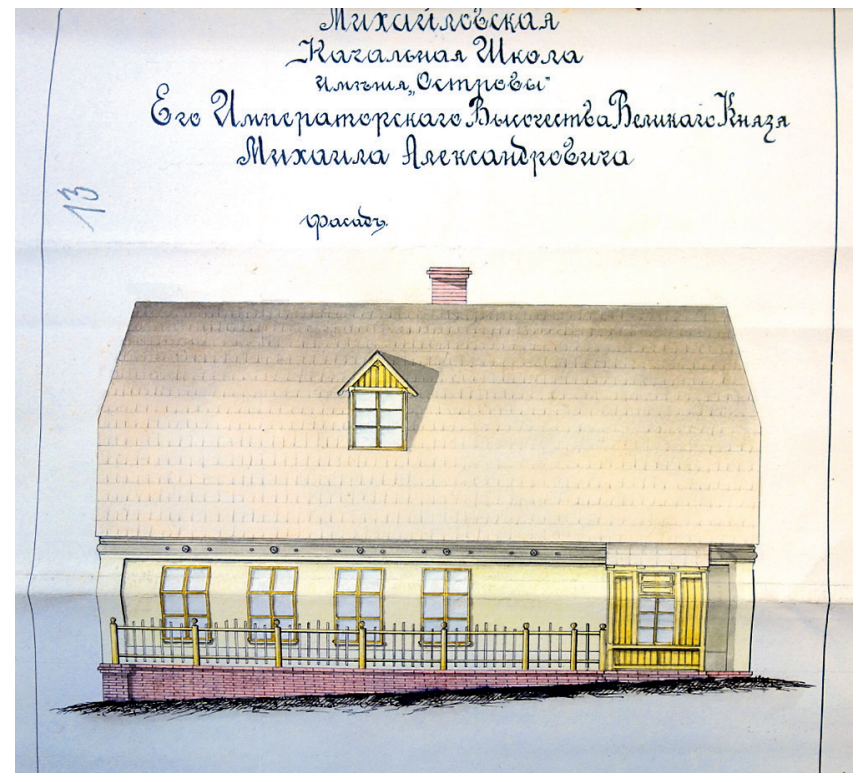

Rys. 1. Fasada szkoły w Ostrowach

Źródło: APŁ. ŁDSz. sygn. 1438.

Formalnie zarząd dóbr Ostrowy przedstawił etat szkoły do zatwierdzenia odpowiednim władzom oświatowym. Z przywołanej korespondencji wyłania się jeszcze jedna bardzo istotna sprawa. Zarząd dóbr informował o tymczasowym odłożeniu pomysłu budowy sali gimnastycznej w szkole [sic! - D.Z. $]^{89}$. Fakt ten potwierdza szczególną troskę Zarządu i W. Szackiego o szkołę w Zagórzu.

\section{W obliczu wielkiej kariery...; wojna}

Szansa na podjęcie pracy w szkole w Zagórzu, umieszczonej przy głównej siedzibie administracji dóbr Ostrowy, do 1914 r. ze względu na uposażenie nauczyciela, przysługującą ordynarię i dodatkowe przywileje, była dla S. Keturakisa bardzo atrakcyjna. W porównaniu do poprzednich placówek mogła uchodzić za luksusową. W życiu Stanisława Keturakisa pojawiła się jednak możliwość dalszego awansu społecznego. Z końcem lata 1914 r. zyskał okazję do objęcia posady pomocnika leśniczego w orłowskiej guberni ${ }^{90}$.

${ }^{89}$ Ibidem, pismo zarządu dóbr z 1 stycznia 1913 r.

90 ApDZ, Listy S. Keturakisa do S. Polakowskiego z 12 lutego i 13 marca 1914 r., sygnatury 739 i 741; w ostatnim z wymienionych listów są jeszcze inne ważne informacje dot. dóbr. S. Keturakis był tam starszym nauczycielem (kierownikiem); pracował od sześciu lat, tj. od 1907 r.; razem z nim pracowała nauczycielka, 


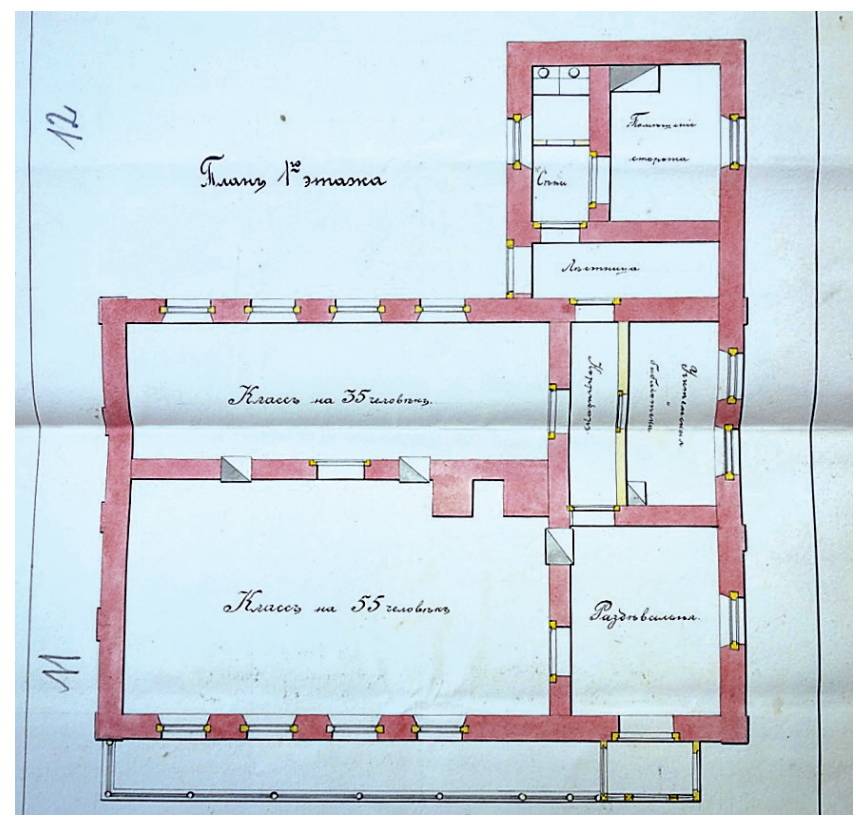

Rys. 2. Parter szkoły w Ostrowach

Źródło: APŁ. ŁDSz. sygn. 1438.

Ponieważ miał świadomość wyjątkowo dobrych warunków, które czekały na tutejszego nauczyciela, zaoferował ją swemu serdecznemu przyjacielowi z Wejwer, Stanisławowi Polakowskiemu. Ten bowiem, mimo że był dobrym nauczycielem, dotychczas cierpiał zwyczajną biedę nauczycielską. On także, jako absolwent Seminarium Nauczycielskiego w Wejwerach (1898 r.), został skierowany do szkół w guberni piotrkowskiej. Tu pracował w szkołach: w Dworszowicach Pakoszowych (1898-1905), Staropolu (1905-1910) i Strzyżowicach od $1910^{91}$.

Stanisław Keturakis, prosząc kolegę o dyskrecję, tak nakreślił warunki, które czekały na nauczyciela w szkole w Zagórzu.

Dom duży, dwie sale, kancelaria, rozbieralnia, mieszkanie dla stróża, 3 pokoje dla nauczyciela, kuchnia, ogród owocowy (młody) i warzywny, orka i nawóz bezpłatnie. Służba na miejscu (stróż i jego rodzina), telefon w mieszkaniu [sic! - D.Z] i połączenie jest dookoła

„nauczyciel pszczelnictwa i ksiądz”. Na Święta Bożego Narodzenia 1913 r. był w Petersburgu u zarządzającego dobrami tj. W. Szackiego. Tam załatwił sobie posadę pomocnika leśniczego w guberni orłowskiej, także w majątku w. ks. Michała. APŁ. ŁDSz, sygn. 2083, op. cit., większość zgromadzonych materiałów dotyczy właśnie pracy w majątku Zagórze. Zob. szerzej o S. Polakowskim D. Złotkowski, Życie, op. cit., s. 52.

${ }^{91}$ Szerzej o S. Polakowskim: D. Złotkowski, Życie, op. cit., s. 119. W szkole w Strzyżowicach pracował do 1923 r., cierpiąc zwyczajną biedę. Ostatnim miejscem jego pracy były Ciągowice (1923-1928). 


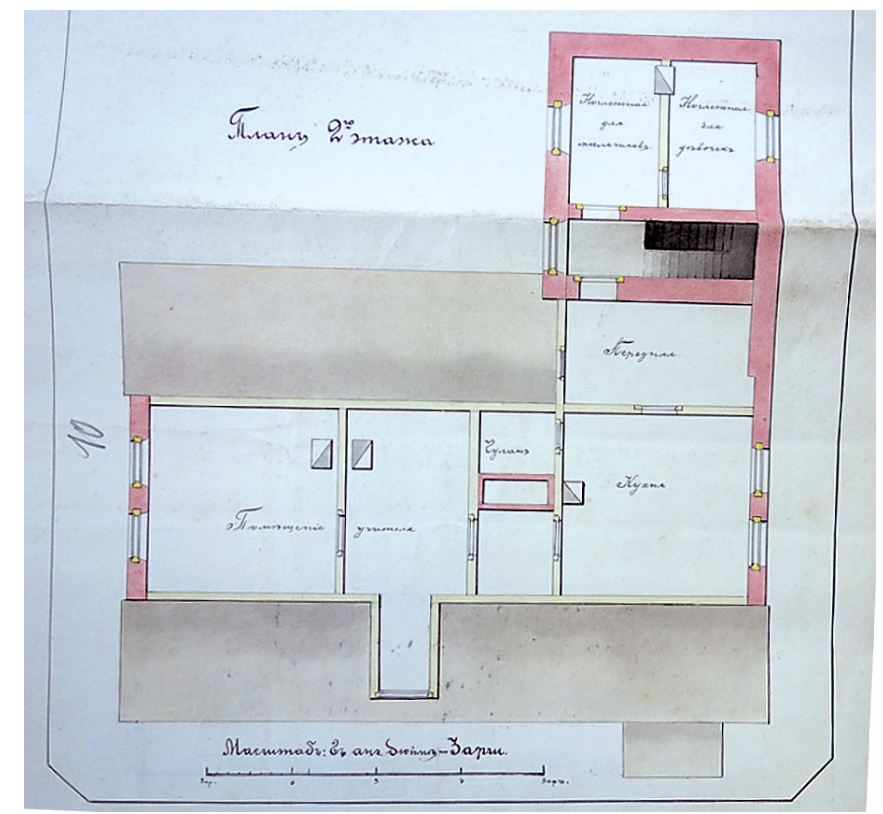

Rys. 3.

Źródło: APŁ. ŁDSz. sygn. 1438.

w promieniu 3 wiorst. Z Częstochową także jest połączenie. Najbliższe miasteczko, gdzie jest poczta i telegraf - Kłobuck, w odległości 1/2 wiorsty od Zagórza, od naszego folwarku, gotówki 1000 rubli rocznie, opał w naturze - ile się spali, kwarta mleka po 5 groszy, doktor i leki bezpłatnie i 10 razy możesz brać konie na wyjazd bryczką lub powozem"92.

Ze względu na wybuch wojny w 1914 r. do podjęcia pracy w szkole w Zagórzu przez Stanisława Polakowskiego nie doszło. Latem 1914 r. kontakty między przyjaciółmi z Seminarium Nauczycielskiego w Wejwerach zostały zerwane. Brak źródeł nie pozwala ustalić dalszych losów Stanisława Keturakisa, „starszego nauczyciela ze szkoły w Zagórzu". Nie wiadomo, czy w obliczu definitywnego opuszczenia Królestwa Polskiego przez Rosjan w 1915 r., także i on ewakuował się. Konieczność wyjazdu w głąb Rosji stała się udziałem tak nauczycieli szkół średnich, jak wiejskich szkół elementarnych. W tym wypadku na miejscu pozostało jednak 869 osób, a do Rosji ewakuowało się zaledwie 509 osób $^{93}$. W której grupie znalazł się S. Keturakis do dziś nie wiadomo.

92 ApDZ., List S. Keturakisa do S. Polakowskiego z Zagórza 13 marca 1914 r., sygn. 741 (zawiera szczegółowy opis warunków pracy). Por. A. Smołalski, op. cit., s. 77.

93 APŁ., Inwentarz zespołu ŁDSz., s. 8. D. Złotkowski, Polacy i Litwini, op. cit. 
Niniejszy artykuł jest skromną próbą uzupełnienia naszej wiedzy o rosyjskim systemie przygotowywania nauczycieli dla szkół elementarnych. Ma on zwrócić uwagę, że obok niewątpliwej rusyfikacji zapewniał młodym ludziom szansę na pewien awans społeczny. Poza wiedzą pedagogiczną nauczyciel otrzymywał podstawowe umiejętności z zakresu ogrodnictwa i rolnictwa. Przyznane stypendium i wynikający stąd nakaz podjęcia pracy we wskazanych przez władze szkołach rodził szereg problemów socjologicznych. Przybliżone losy Stanisława Keturakisa pokazują także znaczenie przyjaźni wyniesionej z seminarium. Wreszcie nagłe przerwanie kariery nauczycielskiej, które nastąpiło latem 1914 r. (a przynajmniej brak możliwości jej odtworzenia na podstawie dostępnych źródeł) pokazują, jak olbrzymi wstrząs społeczny wywołała wojna.

\section{Bibliografia}

\section{Źródła}

Archiwum Państwowe w Częstochowie, ASC Mstów 1904, akt nr 340.

Archiwum Państwowe w Łodzi, Łódzka Dyrekcja Szkolna, O Michałowskiej szkole początkowej w dobrach Ostrowy, sygn. 1438.

Archiwum Państwowe w Łodzi, Łódzka Dyrekcja Szkolna, teczka personalna E. Kesslera, sygn. 2080.

Archiwum Państwowe w Łodzi, Łódzka Dyrekcja Szkolna, teczka S. Keturakisa, sygn. 2083.

Archiwum prywatne D. Złotkowskiego, notatka Stanisława Polakowskiego z dnia 21 lipca 1908 r., sygn. 605, notatka z dnia 20 czerwca 1908 r., sygn. 606.

Archiwum prywatne D. Złotkowskiego, list J. Jasaitisa do S. Polakowskiego, Rzeczyca, 26 sierpnia 1898 r., sygn. 104

Archiwum prywatne D. Złotkowskiego, Listy S. Keturakisa do S. Polakowskiego z 12 lutego i 13 marca 1914 r., sygn. 739 i 74.

List S. Keturakisa do S. Polakowskiego, dat. Godlewo 25 sierpnia 1906 r., sygn. 308.

List S. Keturakisa do S. Polakowskiego, dat. Kołduny 15 listopada 1898 r., sygn. 102

List S. Keturakisa do S. Polakowskiego, dat. m-ce (?) 14 czerwca 1900 r., sygn. 315.

Słownik Geograficzny Królestwa Polskiego, t. II, III, VI, IX, XII, XIII, XIV, Warszawa 1881-1893.

Urzędowe zawiadomienie S. Polakowskiego, ,że jako nauczyciel nie podlega służbie wojskowej”. 25 stycznia 1905 r., sygn. 510.

Opracowania

Araszkiewicz S., Sytuacja szkolnictwa i oświaty w zaborze rosyjskim w latach 1831-1918. Szkolnictwo elementarne. Okres między powstaniem styczniowym a I wojna światowa, w: Dzieje szkolnictwa i oświaty na wsi polskiej, t. 1 do 1918, red. S. Michalski, Warszawa 1982.

Kmiecik Z., Ruch oświatowy na wsi. Królestwo Polskie 1905-1914, Warszawa 1963.

Konarski K., Dzieje szkolnictwa w b. Królestwie Kongresowym 1915-1918, Kraków 1923.

Kucha R., Oświata elementarna w Królestwie Polskim w latach 1864-1914, Lublin 1982.

Kucha R., Z problematyki rozbudowy szkolnictwa elementarnego na Lubelszczyźnie w latach 18641905, w: Szkolnictwo Lubelszczyzny w XVIII-XX wieku. Studia i rozprawy, red. R. Kucha, Lublin 1993, s. 83-100. 
Kudirka J., Veiveriu mokytoju seminarija 1866-1918, Vilnius 1970.

Lipiec J., Warunki gospodarcze szkót elementarnych Królestwa Polskiego. (Studia nad okręgiem częstochowskim lata 1815-1863), Częstochowa 1989.

Lipiec J., Materiały do dziejów szkolnictwa i oświaty ludowej w okręgu częstochowskim u schyłku XIX wieku, „Ziemia Częstochowska” 1965, t. V, s. 59-114.

Podgórska E., Poglady chłopów na funkcję szkoły w drugiej połowie XIX wieku, na przykładzie Łaznowa, „Zeszyty Naukowe Uniwersytetu Łódzkiego. Nauki Humanistyczno-Społeczne” 1969, seria I, nr 63, s. 69-82.

Podgórska E., Szkolnictwo elementarne w Łodzi w latach 18081914, Łódź 1966.

Poznański K., Oświata elementarna w Królestwie Polskim jako przedmiot badań historyczno-pedagogicznych, w: Stan i potrzeby badań nad oświata i wychowaniem w Królestwie Polskim w latach 1815-1915, red. R. Kucha, K. Poznański, Lublin 1989, s. 51-62.

Smołaski A., Uposażenie nauczycieli w Polsce. Zarys historyczny do 1939 roku, Opole 1990.

Szabat B., Szkolnictwo poczatkowe Kielc i powiatu kieleckiego w latach 1864-1915, Kielce 1983.

Szabat B., Walka o szkote polska w okresie rewolucji 1905-1907 r. w guberni kieleckiej, Kielce 1991.

Złotkowski D., Gospodarka w „Dominium Kłobuckim” w XIX i na poczatku XX wieku, Radomsko 2018.

Złotkowski D., Obraz szkoły wiejskiej schyłku XIX wieku w relacjach młodych nauczycieli, w: Rodzinne i pozarodzinne środowiska wychowawcze, red. A. Siedlaczek-Szwed, I. Wagner, Częstochowa 2002.

Złotkowski D., Polacy i Litwini - absolwenci z 1898 roku Seminarium Nauczycielskiego w Wejwerach koło Kowna, w: Wilno i Kresy pólnocno-wschodnie, t. I. Historia i ludzkie losy, red. E. Feliksiak, A. Mironowicz, Białystok 1996, s. 289-313.

Złotkowski D., Życie zawodowe i rodzinne Stanisława Polakowskiego 1880-1943: nauczyciela szkół wiejskich w świetle jego notatek $i$ korespondencji, Częstochowa 1995. 